\title{
FACTORS ASSOCIATED TO SUBJECTIVE WELLBEING IN OLDER ADULTS
}

\author{
Ximena Alvarado San Román ${ }^{1}$, Maria Cecilia Toffoletto², Juan Carlos Oyanedel Sepúlveda3 , Salvador Vargas \\ Salfate ${ }^{4}$ Katiuska Lidice Reynaldos Grandón ${ }^{5}$
}

${ }^{1}$ Ph.D in Nursing. Center for Quantitative Studies. Facultad de Administración y Economía. Universidad de Santiago de Chile. Santiago, Chile. E-mail: xalvarado7@gmail.com

${ }^{2}$ Ph.D in Nursing. School of Nursing. Universidad Andrés Bello. Santiago, Chile. E-mail: mtoffoletto@unab.cl

${ }^{3}$ Ph.D in Law. Department of Management and Public Policies. Facultad de Administración y Economía. Universidad de Santiago de Chile. Santiago, Chile. E-mail: juan.oyanedel@gmail.com

${ }^{4}$ Ph.D. student in Psychology, Universidad de Girona. Centro de Estudios Cuantitativos. Facultad de Administración y Economía. Universidad de Santiago de Chile. Santiago, Chile. E-mail: salvadororama@gmail.com

${ }^{5}$ Ph.D in Nursing. Facultad de Enfermería. Universidad Andrés Bello. Santiago, Chile. E-mail: katiuska.reynaldos@unab.cl

\section{ABSTRACT}

Objective: identify the factors associated with subjective wellbeing in older adults.

Method: analytical, cross-sectional study developed in Chile. The sample consisted of 20,351 seniors, who answered a question on overall life satisfaction in the National Socio-Economic Survey, 2011. Subjective wellbeing was correlated with health, demographic and social indicators. Comparisons of averages, correlations and regressions were applied using the software Statistical Package for the Social Sciences 20.

Results: life satisfaction was associated with increased age; being male; participation in social organizations; being married or living as a couple; having higher education level; higher income; good perceived health status and better health care.

Conclusion: according to the age and income predictors, it can be concluded that, over the years, life satisfaction is reinforced, but in combination with adequate perceived health and income, which permit an excellent quality of life.

DESCRIPTORS: Aged. Quality of life. Happiness. Nursing. Personal satisfaction. Health of the elderly. Social determinants of health.

\section{FACTORES ASOCIADOS AL BIENESTAR SUBJETIVO EN LOS ADULTOS MAYORES}

\section{RESUMEN}

Objetivo: identificar los factores asociados al bienestar subjetivo en los adultos mayores.

Método: estudio analítico, transversal desarrollado en Chile. La muestra correspondió a 20.351 adultos mayores, que respondieron una pregunta sobre satisfacción vital global en la Encuesta de Caracterización Socioeconómica Nacional, 2011. El bienestar subjetivo fue correlacionado con indicadores de salud, demográficos y sociales. Se aplicaron comparaciones de medias, correlaciones y regresiones, mediante el programa Statistical Package for the Social Sciences 20.

Resultados: la satisfacción con la vida se asoció con mayor edad; ser hombre; participación en organizaciones sociales; estar casado o convivir en pareja; tener estudios superiores; mayor ingreso; buena percepción del estado de salud; mejor atención sanitaria.

Conclusión: al observar los predictores edad e ingresos, se puede concluir que el paso de los años refuerza la satisfacción con la vida pero, en confluencia con una adecuada percepción de salud e ingresos, que permitan una calidad de vida óptima.

DESCRIPTORES: Anciano. Calidad de vida. Felicidad. Enfermería. Satisfacción personal. Salud del anciano. Determinantes sociales de la salud. 


\section{FATORES ASSOCIADOS AO BEM-ESTAR SUBJETIVO DOS IDOSOS}

\section{RESUMO}

Objetivo: identificar os fatores associados ao bem-estar subjetivos dos idosos.

Método: estudo analítico, transversal, realizado no Chile. A amostra correspondeu a 20.351 idosos que responderam a uma pergunta sobre satisfação vital global no Inquérito de Caracterização Socioeconômica Nacional, 2011. O indicador de bem-estar subjetivo foi correlacionado com indicadores de saúde, demográficos e sociais. Foram comparadas médias e análise de correlação e regressão com o programa Statistical Package for the Social Sciences 20.

Resultados: a satisfação com a vida associou-se com maior idade; ser homem; participação em organizações sociais; ser casado ou viver junto; ter estudos superiores; maior renda; boa percepção do estado de saúde e maior atenção sanitária.

Conclusão: ao observar os preditores idade e renda pode-se concluir que o passar dos anos reforça a satisfação com a vida, mas em confluência com uma adequada percepção de saúde e renda que permitam uma qualidade de vida ótima.

DESCRITORES: Idoso. Qualidade de vida. Felicidade. Enfermagem. Satisfação pessoal. Saúde do idoso. Determinantes sociais da saúde.

\section{INTRODUCTION}

The aging process is growing at an accelerated and proportional pace in Latin America and the Caribbean. Between 1975 and 2000, the population aged 60 years and older increased from $6.5 \%$ to $8.2 \%$. The projected rate for 2025 is $15 \%$ and, for $2050,24 \%$, corresponding to a growth rate of $2.4 \%$ between 2025 and $2050 .{ }^{1}$

In the current global context of aging, promoting the subjective wellbeing of older adults through social support, with a view to enhancing their satisfaction with life, has represented a challenge not only for public policy makers, ${ }^{2}$ but also for health professionals, who are responsible for working with them, directly, mainly nursing professionals.

The concept of subjective wellbeing (SW) refers to the assessments people make of their own lives, which can be judgments, such as satisfaction with life, assessments based on feelings, including the states of mind and emotions. ${ }^{3}$

Different factors can contribute to a better wellbeing and how older adults perceive it. Factors like age, gender, education, degree of social integration, support networks and professional activities are clearly related with perceived wellbeing, happiness and quality of life, besides social participation at home, in politics and religion. ${ }^{4-5}$

What health is concerned, autonomy and functionality are determining factors in the subjective wellbeing of older adults. In a Brazilian study that analyzed the association between health-related behaviors and feelings of happiness, a strong association was found between happiness and the number of morbidities, perceived quality of health and the level of disabilities. ${ }^{6}$ In another study, it was demonstrated through phenomenological analysis that happiness is related to family and social contact, as well as autonomy and ability to work, which grant feelings of value, self-esteem and wellbeing. ${ }^{7}$

Social support to achieve better health, especially from the perspective of the nursing profession, plays a fundamental role as, through its interventions, it can contribute to the satisfaction with life of older adults. In a study developed in Brazil to get to know the importance of nursing care for health promotion in the lives of older adults, findings showed that their biological aspect improved, such as greater flexibility and good joint mobility, besides increasing and improving the social interactions. The authors concluded that nursing has great creative power, by offering care that favors joy, wellbeing and happiness. ${ }^{8}$

In another study, intended to configure the role of nursing in care delivery to older adults in the context of Primary Health Care (PHC), the need was highlighted to move from actions centered in the biological aspect to the social aspect. They highlight the accomplishment of individual, group and family activities, valuing the sociocultural context of older adults with a view to healthy and highquality aging. ${ }^{9}$

In view of the health promotion paradigm, the biomedical, fragmented and curative care needs to be overcome. To understand health as a dimension of subjective wellbeing, the nurses need to redimension the care, changing the perspective from normative education, which is hardly effect and has little social impact, to actions to promote the adoption of healthy lifestyles and social inclusion. ${ }^{8}$

In that sense, the following question emerges: What health, demographic and social factors are associated with the subjective wellbeing of older adults? Analyzing the factors associated with subjective wellbeing in older adults permits identifying, by means of the nursing assessment, what risk factors influence their reduced subjective wellbeing. This allows nurses, together with the interdisciplin- 
ary team, to make the necessary interventions to reduce the impact of these factors and contribute to improve the perceived wellbeing of this age group. In addition, the knowledge produced in this study contributes to the development of public policies on the theme, emphasizing the preparation of human resources who attend to the needs of older adults, in order to guarantee the health, wellbeing and equity of this age group.

Based on the above, the objective in this study was to identify the factors associated with subjective wellbeing in older adults.

\section{METHOD}

A cross-sectional, analytic study was undertaken. It was developed in Chile, based on secondary data from the National Socioeconomic Survey (CASEN), 2011, involving people aged 60 years or older, male and female, from the urban and rural areas. The sample was designed by the Social Development Department of the Chilean Government. A home-based territorial sampling model was adopted, permitting estimation at the community level. The sample was representative of the urban and rural population in the 15 regions of the country. The sample assumed maximum variance for all of its estimators at the community level and was later expanded based on population projections.

For the sake of this study, a subsample of 20,351 older adults was used, including 7,551 men $(37 \%)$ and 12,800 women $(63 \%)$, who answered the question about satisfaction with life. Being the selection based on a systematic series of random community-level samples based on the premise of maximum variance, the subsample was a sample representative of people aged 60 years or older at the national level. The sampling criterion was not clinical but population based. ${ }^{10}$

The dependent variable in this study was subjective wellbeing, specifically addressing the dimension life satisfaction. The question on life satisfaction included in the survey was the modified Cantril scale (also known as Overall Life Satisfaction), as it was adjusted to a scale from 1 to 10 points. Cantril created this scale to measure people's perception of their current life. Due to its simplicity, it has been widely used in studies like the World Values Survey and the European Survey. Similarly, its modified version (with a score ranging from 1 to 10) was included in the 2011 CASEN. The United National Development
Program (UNDP) also considered it in the elaboration of the 2012 Human Development Report. ${ }^{11}$ The question was: all things considered, how satisfied are you with your life right now? in which 1 means that you are "totally dissatisfied" and 10 "totally satisfied", how do you rate yourself?

Three dimensions or sets of independent variables were used, based on the information from the CASEN survey, related to: Health Dimension (health condition: 1 very bad to 7 very good, considering 1-2: low; 3-5: average and 6-7: high; health system: private, public, armed forces; Nutritional condition: normal weight, overweight, obese, low weight; functional loss to perform activities alone: yes, no; functional loss to recall things: yes, no; functional loss to go out alone: yes, no). Demographic Dimension (age: 60 to 69 years, 70 to 79 years, 80 to 89 years, 90 years or older; sex: male, female; marital status: married, divorced, annulled, living with partner, single, widowed; educational level: postgraduate, professional, higher technician, special education). Social Dimension (participates in social organizations, income, work).

Using Statistical Package for the Social Sciences (SPSS) version 20, univariate, bivariate and multivariate operations were executed. The first analysis level involved descriptions of each variable, presented in tables with means, standard deviation, minima and maxima. The second analysis level considered the existence of associations between subjective wellbeing and the different continuous variables, included in the model through Pearson's correlation coefficient or tests of difference of proportions or means ( $\mathrm{t}$ and Anova tests). On the other hand, the bivariate association between life satisfaction and scale variables was analyzed using Pearson's correlation coefficient. The third analysis level was an explanatory analysis of subjective wellbeing, using the stepwise multiple linear regression technique. This permitted explaining the behavior of a dependent variable based on a series of independent variables and including them in the analysis through groups of variables or model steps. In that sense, the life satisfaction was the dependent variable or to explain and the health, demographic and social variables were the independent or explanatory variables.

The project received approval from the Institutional Ethics Committee (Folio: L1/CECENF/73) and, to be able to use the CASEN 2011 database, authorization was requested from the Chilean Social Development Department. 


\section{RESULTS}

The mean coefficient of the dependent variable life satisfaction of older adults corresponded to 7,055 $(\mathrm{SD}=2,225)$, lower than in the rest of the population $(\mathrm{M}=7,202, \mathrm{SD}=2,173)$. This intergroup difference was statistically significant, $t(3843536,809)=-95.578$, $p<0,001$ (Table 1).
What the variable health condition is concerned, the group of people with a high health condition score an average $7,682(\mathrm{SD}=1,999)$ on life satisfaction, followed by the intermediary category $(M=6,834$, $\mathrm{SD}=2,155)$ and the lowest $(\mathrm{M}=5,351, \mathrm{SD}=2,821)$. A statistical significant relation was found between both indicators, being significance set at $1 \%$, as shown by a high Pearson coefficient $(\mathrm{r}=0.286)$.

Table 1 - Descriptive statistics of factors related to the Health Dimension. Santiago de Chile, Chile, 2014. $(n=20,351)$

\begin{tabular}{|c|c|c|c|c|}
\hline Factors Health Dimension & Mean (M) & $\begin{array}{c}\text { Standard } \\
\text { deviation (SD) }\end{array}$ & Hypothesis test & $\mathrm{p}$ \\
\hline Life satisfaction & 7,055 & 2,225 & $\mathrm{t}(3843536,809)=-95.578$ & $0,000^{*}$ \\
\hline \multicolumn{5}{|l|}{ Health system } \\
\hline Private & 7,935 & 1,969 & $F(8,2567186)=9054.626$ & $0,000^{\dagger}$ \\
\hline Public & 7,585 & 2,020 & & \\
\hline Armed forces & 7,594 & 2,163 & & \\
\hline \multicolumn{5}{|l|}{ Nutritional status } \\
\hline Normal weight & 7,181 & 2,216 & $F(3,2521026)=10343.166$ & $0,000^{\dagger}$ \\
\hline Overweight & 7,043 & 2,184 & & \\
\hline Obesity & 6,869 & 2,073 & & \\
\hline Low weight & 6,209 & 2,339 & & \\
\hline \multicolumn{5}{|c|}{ Functional loss to perform activities alone } \\
\hline Yes & 6,426 & 2,382 & $\mathrm{t}(383441.407)=158.087$ & $0,000^{*}$ \\
\hline No & 7,141 & 2,189 & & \\
\hline \multicolumn{5}{|l|}{ Functional loss to recall things } \\
\hline Yes & 6,313 & 2,214 & $t(552672.863)=-229.752$ & $0,000^{*}$ \\
\hline No & 7,188 & 2,199 & & \\
\hline \multicolumn{5}{|l|}{ Functional loss to go out alone } \\
\hline $\mathrm{Si}$ & 6,488 & 2,376 & $\mathrm{t}(482323.514)=-158.928$ & $0,000^{*}$ \\
\hline No & 7,150 & 2,184 & & \\
\hline
\end{tabular}

* student's t; ${ }^{\dagger}$ Variance analysis (ANOVA).

Concerning the health system, in Table 1, it is observed that the higher mean for life satisfaction was found for the group in the private system $(7,935)$, followed by the armed forces $(7,594)$ and the public system $(7,585)$. The bivariate combination with the nutritional status demonstrates that the higher coefficient for life satisfaction is found in people of normal weight. With respect to physical disability, the group that faces difficulties to perform activities alone, concentrate and learn things and go out alone without help or a companion obtains a lower average score on the life satisfaction variable than their peers without declared restrictions. A statistically significant intergroup difference was found for all variables in the Health Dimension $(p<0.001)$. 
Table 2 - Multiple linear regression of factors related to Health Dimension. Santiago de Chile, Chile, 2014. $(n=20,351)$

$$
\text { Non-standardized coefficients Typified coefficients }
$$

$\mathbf{t}$

Sig

\begin{tabular}{|c|c|c|c|c|c|}
\hline & B & Typ error & Beta & & \\
\hline (Constant) & 5.176 & .009 & & 577.147 & 0.000 \\
\hline Health status & .424 & .001 & .267 & 404.403 & $0.000^{\prime}$ \\
\hline Public & -.269 & .006 & -.038 & -41.666 & $0.000^{\circ}$ \\
\hline Private & .401 & .008 & .045 & 49.133 & $0.000^{\circ}$ \\
\hline Nutritional status & .092 & .003 & .020 & 32.929 & $0.000^{\circ}$ \\
\hline $\begin{array}{l}\text { Difficulties to perform } \\
\text { activities alone }\end{array}$ & .008 & .005 & .001 & 1.465 & 0.143 \\
\hline Difficulties to recall things & -.657 & .004 & -.108 & -167.690 & $0.000^{\circ}$ \\
\hline Difficulties to go out alone & -.001 & .005 & .000 & -.226 & 0.821 \\
\hline
\end{tabular}

"Statistical significance: $\mathrm{p}<0.001$.

In Table 2, the results of the regression model are presented $\mathrm{F}(9,2493275)=30948.788$, $\mathrm{p}<0.001$, which explains $10.49 \%$ of the variance in the dependent variables. All variables were statistically significant, except for the difficulties to perform activities and go out alone. Thus, a higher perceived health status, having a private health insurance and normal weight increase the average subjective wellbeing.

What the Demographic Dimension is concerned, it was observed that, for the relation between subjective wellbeing and age, the highest life satisfaction score was in the age range between 80 and 89 years. Pearson's r coefficient was statistically significant but low (0.014), indicating that, the higher the age, the higher the satisfaction with life.

Table 3 - Descriptive statistics for factors related to Demographic Dimension. Santiago de Chile, Chile, 2014. $(n=20,351)$

\begin{tabular}{|c|c|c|c|c|}
\hline Factors Demographic Dimension & Mean (M) & Standard deviation (SD) & Hypothesis test & p \\
\hline \multicolumn{5}{|l|}{ Sex } \\
\hline Man & 7,189 & 2,156 & $\mathrm{t}(2539503,300)=-88.810$ & $0.000^{*}$ \\
\hline Woman & 6,943 & 2,274 & & \\
\hline \multicolumn{5}{|l|}{ Age } \\
\hline 60 to 69 years & 7,053 & 2,209 & & $0.014^{\dagger}$ \\
\hline 70 to 79 years & 6,957 & 2,204 & & \\
\hline 80 to 89 years & 7,288 & 2,311 & & \\
\hline 90 or higher & 7,272 & 2,270 & & \\
\hline \multicolumn{5}{|l|}{ Estado civil } \\
\hline Married & 7,265 & 2,160 & $F(6,2581067)=4360.485$ & $0.000^{\ddagger}$ \\
\hline Divorced & 7,151 & 2,363 & & \\
\hline Annulled & 7,063 & 2,359 & & \\
\hline Living together & 6,963 & 2,375 & & \\
\hline Single & 6,954 & 2,339 & & \\
\hline Widowed & 6,832 & 2,157 & & \\
\hline \multicolumn{5}{|l|}{ Educational level } \\
\hline Postgraduate & 8,345 & 1,789 & $\mathrm{~F}(10.2581063)=4532.957$ & $0.000^{\ddagger}$ \\
\hline Professional & 7,670 & 1,981 & & \\
\hline Higher technician & 7,938 & 2,020 & & \\
\hline Special education & 5,800 & 2,255 & & \\
\hline
\end{tabular}


What the sex is concerned, a lower average life satisfaction was observed for women than for men, with a statistically significant difference. What the age is concerned, the highest life satisfaction scores were in the age range between 80 and 89 years. Pearson's r statistics was statistically significant but low, corresponding to only 0.014 . The marital status was another variable included in this dimension, based on which it could be observed that older adults presented the highest average life satisfaction, while widowers presented the lowest mean life satisfaction, with statistically significant differences. Older adults with a higher education degree and postgraduate education reported higher life satisfaction levels, as opposed to the group with special education. The difference between these groups was statistically significant.

Table 4 - Multiple linear regression of factors related to Demographic Dimension. Santiago de Chile, Chile, 2014. $(n=20,351)$

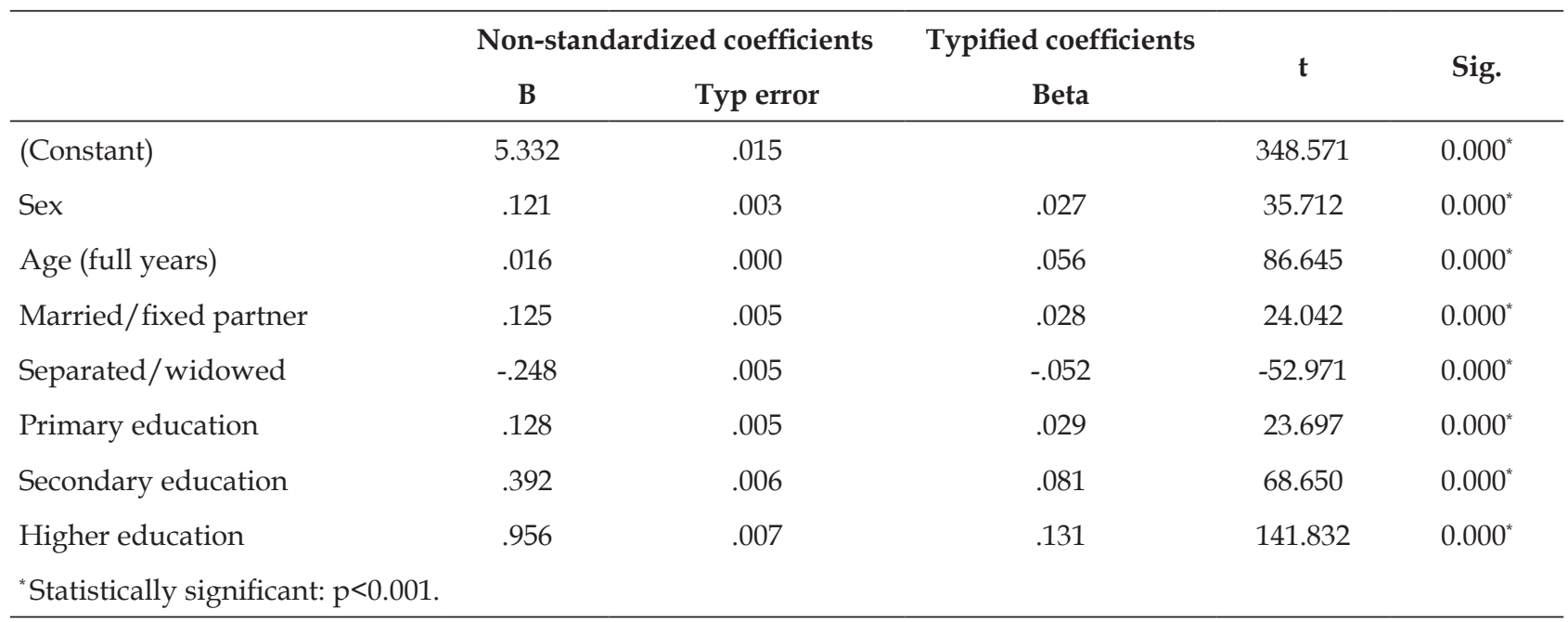

When all variables were included in a multiple linear regression model, the analysis is statistically significant, $F(11,2581062)=6616.666, p<0.001$, explaining $2.742 \%$ of the variance in the dependent variable. It should be highlighted that the marital status was recoded in fictitious variables: married/ living with partners and separated/widowed, using single people as a reference category. The model results evidenced that all variables were statistically significant to predict subjective wellbeing. In addition, being a man, married or living with a fixed partner and having primary, secondary or higher education increased the mean life satisfaction coefficient (Table 4).

In the Social Dimension, the first variable was the participation in organizations, highlighted that older adults who do not participate in any organization have a mean life satisfaction coefficient corresponding to $6.961(\mathrm{SD}=2,233)$. This coefficient was only higher than for groups of neighbors $(\mathrm{M}=6,939$, $\mathrm{SD}=2,247)$, self-help groups in health $(\mathrm{M}=6,619$, $\mathrm{SD}=2,094)$ and cultural identity groups $(\mathrm{M}=6,500$, $\mathrm{SD}=1,822)$. On the opposite, the highest scores were found for people participating in juvenile or student groups $(\mathrm{M}=7,947, \mathrm{SD}=1,769)$ and volunteers $(\mathrm{M}=7,851, \mathrm{SD}=1,821)$. The intergroup differences are statistically significant, $\mathrm{F}(11,2581062)=2047.452$, $\mathrm{p}<0.001$, indicating that both variables are related.

The income, on the other hand, measured in quintiles, evidences that older adults with greater purchasing power show higher levels of subjective wellbeing $(M=7,579, S D=2,058)$. The drop in life satisfaction was gradual, in line with the income decrease, with averages of 7,313 (SD=2,150), 7,035 $(\mathrm{SD}=2,131), 6,888(\mathrm{SD}=2,288)$ and $6,549(\mathrm{SD}=2,341)$ for the remaining quintiles. Pearson's statistic reveals a moderate $(\mathrm{r}=0.152)$ and statistically significant association.

The final variable selected for the analysis was the inclusion in the job market, which revealed that the older adults who worked presented an average life satisfaction score of $7.347(\mathrm{SD}=2.179)$, being higher than for their inactive peers $(M=6.965$, $\mathrm{SD}=2.231$ ). The variables were significantly associated, $t(1031072,051)=119.011, p<0.001$, as evidenced by the t-test for independent samples. 
Table 5 - Multiple linear regression of factors related to Social Dimension. Santiago de Chile, Chile, 2014. $(n=20,351)$

\begin{tabular}{|c|c|c|c|c|c|}
\hline & \multicolumn{2}{|c|}{ Non-standardized coefficients } & \multirow{2}{*}{$\begin{array}{c}\text { Typified coefficients } \\
\text { Beta }\end{array}$} & \multirow{2}{*}{$t$} & \multirow{2}{*}{ Sig } \\
\hline & B & Typ error & & & \\
\hline (Constant) & 6.249 & .004 & & 1743.485 & $0.000^{*}$ \\
\hline Participation in social organizations & .241 & .003 & .051 & 79.717 & $0.000^{*}$ \\
\hline $\begin{array}{l}\text { National Autonomous Income } \\
\text { Quintile }\end{array}$ & .220 & .001 & .135 & 196.477 & $0.000^{*}$ \\
\hline Work & .139 & .004 & .027 & 39.609 & $0.000^{*}$ \\
\hline
\end{tabular}

"Statistically significant: $\mathrm{p}<0.001$.

When the variables were included in a multiple linear regression model, the explained variance corresponded to $3.223 \%$, being statistically significant, $\mathrm{F}(4,2357732)=19629.002$, $\mathrm{p}<0.001$, using life satisfaction as the dependent variable. The indicator participation in social organizations was recoded in two categories to represent the competition between the groups and the absence of this attribute in older adults. All variables were significant in the prediction of the dependent variable, showing a positive relation with life satisfaction. Thus, the participation in organizations, the income and inclusion in the job market enhanced the subjective wellbeing (Table 5).

\section{DISCUSSION}

The analysis developed in this study confirms that, for older adults, the most important dimension to explain their life satisfaction is truly their health, but specifically their self-perceived health. ${ }^{12-13} \mathrm{~A}$ Spanish study on quality of life, happiness and life satisfaction in older adults ratifies the present results, highlighting health as a priority condition for wellbeing, followed by family and social relationships and adaptation. ${ }^{14}$

Among the factors in the Health Dimension, a high perceived health status, having a private health insurance and normal weight increase the mean subjective wellbeing. As for the weight, the findings are supported by a Brazilian study that demonstrated that older adults with a body mass index superior to 40 present lower prevalence rates of happiness. ${ }^{6}$

What the functional limits of older adults are concerned, an association was found with low subjective wellbeing. In view of these results, the evidence tends to display a larger proportion of functional limits in women and people with a low education level. In an American study on disability, participation and subjective wellbeing in older adults, findings showed that people who reported disability presented significantly lower scores than people without alterations. ${ }^{15}$ The literature refers that physical impediments play a determinant role in health assessment and, therefore, in the wellbeing of older adults. ${ }^{4}$ In line with these results, in a study developed in Brazil, which related functional capacity with quality of life, older adults with a higher level of functional disabilities presented lower quality of life scores than people without functional alterations. ${ }^{16}$

In line with the functionality, the evidence demonstrates that practicing physical exercise influences the quality of life of older adults. In a study undertaken to identify the sociodemographic characteristics, social connection, physical environment and physical and mental factors related to physical exercise, it was demonstrated that gender, quality of life, disability, , age, depression, anxiety, employment, type of housing and cognitive ability were significant factors associated with physical exercise. $^{17}$

Concerning the Demographic Dimension and its factors in the course of the lifecycle, men sustained higher levels of life satisfaction than women. These data coincide with a study developed in Chile, which measures life satisfaction, happiness and health in the Chilean population. ${ }^{18}$ In line with the evidence, being a man with greater social integration and higher education level was associated with the life satisfaction. ${ }^{19}$

Also related to the educational background and revenue, in a study developed in Turkey, socioeconomic and demographic determinants were related with the perceived health and happiness of 870 older adults, showing that $61.10 \%$ gained the lowest income level, and $80.60 \%$ a low educational level. Although most participants felt happy, only $46.59 \%$ considered their health was good..$^{20}$ 
Besides the findings related to sex, the variables age, marital status and education showed a statistically significant relation with subjective wellbeing, explaining that the oldest adults in the highest age range (80 and 90 years), married or living with a partner and with the highest education level presented higher levels of subjective wellbeing.

Studies indicate that the happiest older adults live in couples belonging to the highest levels, but are younger than in this study. ${ }^{21-22}$

Based on the collected information, a profile could be outlined of older adults with reduced subjective wellbeing, being mainly women between 70 and 79 years of age, separated, with low education and income levels, who do not participate in social organizations, face difficulties to recall things and have deficient health and nutritional conditions.

In a study undertaken in Brazil involving 1,339 older adult women, it was demonstrated that, the higher the age and the lower the educational level, the higher the functional disability. The highest age group was associated with a lower quality of life in operational activities and social participation. ${ }^{23}$ In another Brazilian study, using a sample of 624 older adults between 60 and 96 years of age, an association was found between functional disability for basic activities of daily living and age, alcohol consumption, depressive symptoms and frailty, and between instrumental activities of daily living and age, illiteracy, multigenerational family arrangements, hospitalization and frailty. ${ }^{24}$

These study results are in line with another study that aimed to estimate the prevalence of frailty in older adult women and to identify possible associations between frailty and sociodemographic variables. The results demonstrated that, among the older adult women with some degree of frailty, an association was verified with age, education and monthly income. ${ }^{25}$

Concerning the factors related to the Social Dimension, as observed, the variables participation in organizations, income and inclusion in the job market significantly predicted life satisfaction and therefore increased the subjective wellbeing. The results found support the findings from other studies on professional activities ${ }^{4,7}$ and participation in organizations. ${ }^{5}$

Besides the participation in organizations and the inclusion in the job market, although not inves- tigated in this study, extraversion was a variable studied in the group of older adults and related with their wellbeing. In a Spanish study, an association was found between the extraversion and wellbeing of older adults, besides determining the type of activity performed, including educational, religious, leisure and domestic activities. ${ }^{26}$

What the limitations are concerned, this study built on secondary databases, which sometimes do not contain sufficient information, although the information was sufficiently useful in this study to attend to the proposed objective. Another limitation was the lack of studies that analyzed the same factors associated with the demographic and mainly Social Dimension. Most studies focus on the Health Dimension.

\section{CONCLUSION}

The most important results in this study clearly evidence that the main explanatory component of satisfaction with life in older adults is selfperceived health. Based on the other most important predictors, it can be argued that this group's age strengthens the life satisfaction, but in combination with an appropriate perceive health and revenue, which permit supporting an excellent quality of life. In addition, they provide the nursing professionals with important data in the monitoring of older adults to prevent adverse consequences like disability, deterioration of health and hospitalization, among others.

\section{REFERENCES}

1. Centro Latinoamericano y Caribeño de Demografía (CELADE), División de Población de la Comisión Económica para América Latina y el Caribe (CEPAL) y Fondo de Población de las Naciones Unidas (UNFPA). El envejecimiento y las personas de edad. Indicadoressociodemograficos para America latina y el Caribe [Internet]. Santiago: CELADE; 2009. [cited 2015 Aug 02]. Available from: http://repositorio. cepal.org/handle/11362/1350

2. Calvo E, Martorell B. La salud del adulto mayor en Chile: una responsabilidad compartida por las personas, las empresas y el Estado. In: Calvo E, Martorell B. Construyendo políticas públicas para una sociedad que envejece. Santiago de Chile: Expansiva; 2008.

3. Tov W, Diener E. Culture and subjective well-being. Social Indicators Research Series. 2009; 38:9-41. 
4. Silva PA. Individual and social determinants of selfrated health and well-being in the elderly population of Portugal. Cad Saúde Pública [Internet]. 2014 Nov [cited 2015 Sep 10];30(11):1-15. Available from: http://www.scielo.br/pdf/csp/v30n11/0102-311Xcsp-30-11-2387.pdf

5. Herrera MSP, Elgueta EPR, Fernández MBL. Social capital, social participationand life satisfaction among Chilean older adults. Rev Saúde Pública [Internet]. 2014 Oct [cited 2015 Sep 14]; 48(5):739-49. Available from:http:/ / www.ncbi.nlm.nih.gov/pmc/articles/ PMC4211572/pdf/0034-8910-rsp-48-5-0739.pdf

6. Lima MG, Barros MBA, Alves MCGP. Happiness in the elderly: an epidemiologicalapproach in the ISACamp 2008 study. Cad Saúde Pública [Internet]. 2012 Dec [cited 2015Sep 15]; 28(12):2280-92. Available from: http://www.scielo.br/pdf/csp/v28n12/07.pdf

7. Luz MMC, Amatuzzi MM. Experiences of happiness in elderly people. Estud Psicol [Internet]. 2008 Abr-Jun [cited 2015 Sep 18]; 25(2):303-7. Available from: http://www.scielo.br/pdf/estpsi/v25n2/ a14v25n2.pdf

8. Victor JF, Vasconcelos FF, Araujo AR, Ximenes LB, Araújo TL. Happy age group: nursing care for the promotion of health in the third age. Rev Esc Enferm USP. [Internet] 2007 [cited 2015 Sep 22]; 41(4):724-30. Available from: http://www.scielo.br/pdf/reeusp/ v41n4/25.pdf

9. Pinheiro G, Alvarez A, Pires D. The configuration of the work of nurses in care of the elderly in the Family Healthcare Strategy. Cienc Saúde Colectiva [Internet]. 2012 Ago [cited 2015 Sep 24]; 17(8):2105-15. Available from: http://www.scielo.br/pdf/csc/v17n8/21.pdf

10. Ministerio de Desarrollo Social de Chile. Encuesta de caracterización socioeconómica nacional (CASEN). Octubre del 2011 y Enero del 2012, metodología y cuestionário. Chile: 2011. Available from:http:// interwp.cepal.org/badehog/pdf/7/1047/ Casen2011cues.pdf

11. Cantril H. The pattern of human concerns. New Brunswick (US): Rutgers University Press; 1965.

12. Vázquez C, Hervás G, Rahona J, Gómez D. Bienestar psicológico y salud: aportaciones desde la psicología positiva. APCS [Internet]. 2009 [cited 2015 Sep 24]; 5:15-28. Available from:http://institucional.us.es/ apcs/doc/APCS_5_esp_15-28.pdf

13. Vera P, Celis K. Positive and negative affect as mediator of the relatioship optimism-health: evaluation of a structural model universitas. Psychologica [Internet]. 2014 jul-aug [cited 2015 Sep 25]; 13(2):15-23. Available from: http://revistas.javeriana.edu.co/index.php/ revPsycho/article/viewFile/7384/8743

14. Rodriguez A, Goñi A. La estructura tridimensional del bienestar subjetivo. Anales de Psicología [Internet]. 2011 May [cited 2015 Oct 02]; 27(2):32732. Available from: http://www.redalyc.org/ pdf/167/16720051008.pdf

15. Llobet MP, Ávila NR, Farràs JF, Canut MTL.Quality of life, happiness and satisfaction with life of individuals 75 years old or older cared for by a home health care program. Rev Latino-Am Enfermagem[Internet]. 2011 May-Jun [cited 2015 Oct 02]; 19(3):467-75. Available from: http://dx.doi.org/10.1590/S010411692011000300004

16. Tavares DMS, Santos DM, Dias FA. Functional capactiy, morbidities and quality of life of the elderly. Texto Contexto Enferm [Internet]. 2012 Jan-Mar [cited 2015 Oct 02]; 21(1):112-20. Available from:http:// www.scielo.br/pdf/tce/v21n1/en_a13v21n1.pdf

17. McKee G, Kearney PM, Kenny RA. The factors associated with self-reported physical activity in older adults living in the community. Age Ageing,[Internet]. 2015 Jul [cited 2016 Jun 14] 44(4):586-92. Available from: http://ageing.oxfordjournals.org/content/44/4/586. full.pdf+html

18. FreedmanVA, Stafford F, Schwarz N, Conrad F, Cornman JC. Disability, participation, and subjective wellbeing among older couples. Soc Sci Med [Internet]. 2012 [cited 2015 Oct 10]; 74(4):588-96. Available from:http:/ /www.ncbi.nlm.nih.gov/pmc/ articles/PMC3371257/pdf/nihms348529.pdf

19. Moyano E, Ramos N. Bienestar subjetivo: midiendo satisfacción vital, felicidad y salud en población chilena de la región del Maule. Universum [Internet]. 2007 [cited 2016 Jun 14]; 2(22):184-200. Available from: http:/ / www.scielo.cl/scielo.php?script=sci_ arttext\&pid=S0718-23762007000200012\&lng=es\&tl $\mathrm{ng}=\mathrm{es}$

20. Ergin I, Mandiracioglu A. Demographic and socioeconomic inequalities for self-rated health and happiness in elderly: the situation for Turkey regarding world values survey between 1990 and 2013. Arch Gerontol Geriatr.2015Sep-Oct; .61(2): 224-30.

21. Oishi S, Diener E. Can and should happiness be a policy goal? Policy insights from the behavioral and brain Sciences.[Internet]2014[cited 2015 Oct 10]; 1(1):195-203. Available from: http://bbs.sagepub. com/content/1/1/195.full.pdf+html

22. Cardona JL, Villamil MM, Henao E, Quintero A. Concept of loneliness, and perception of their 
current life moment, among elderly adults from Bello, Colombia, 2007. Rev Fac Nac Salud Pública [Internet]. 2009 May-Ago [cited 2015 Oct 10]; 27(2):15363. Available from: http://www.scielo.org.co/pdf/ rfnsp/v27n2/v27n2a06.pdf

23. Soares MBO, TavaresDMS, Diniz DMA, Geib S. Morbidity, functional capacity and quality of life of elderly women. Esc Anna Nery [Internet]. 2010 Oct-Dec [cited 2015 Oct 20]; 14 (4):705-11. Available from: http://www.scielo.br/pdf/ean/v14n4/ v14n4a08.pdf

24. Virtuoso Júnior JS, Martins CA, Roza LB, Paulo TRS, Ribeiro MCL, Tribess S. Prevalence of disability and associated factors in the elderly. Texto Contexto
Enferm [Internet] 2015 Abr-Jun [cited 2016 Aug 18]; 24(2):521-9. Available from: http://www.scielo.br/ pdf/tce/v24n2/0104-0707-tce-24-02-00521.pdf

25. Duarte MCS, Fernandes MGM, Rodrigues RAP, Nobrega MML. Prevalência efatores sociodemográficos associados à fragilidade em mulheres idosas. Rev Bras Enferm [internet]. 2013 Nov-Dec [cited 2015 Oct 29]; 66(6):901-6. Available from: http://www.scielo.br/ pdf/reben/v66n6/14.pdf

26. Rubio L, Dumitrache CG, Rubio-Herrera R. Activity involvement and extraversion as predictors of psychological wellbeing in older people. Rev Esp Geriatr Gerontol. 2016; 51(2):75-81. 